\title{
Colonization and usage of an artificial urban wetland complex by freshwater turtles
}

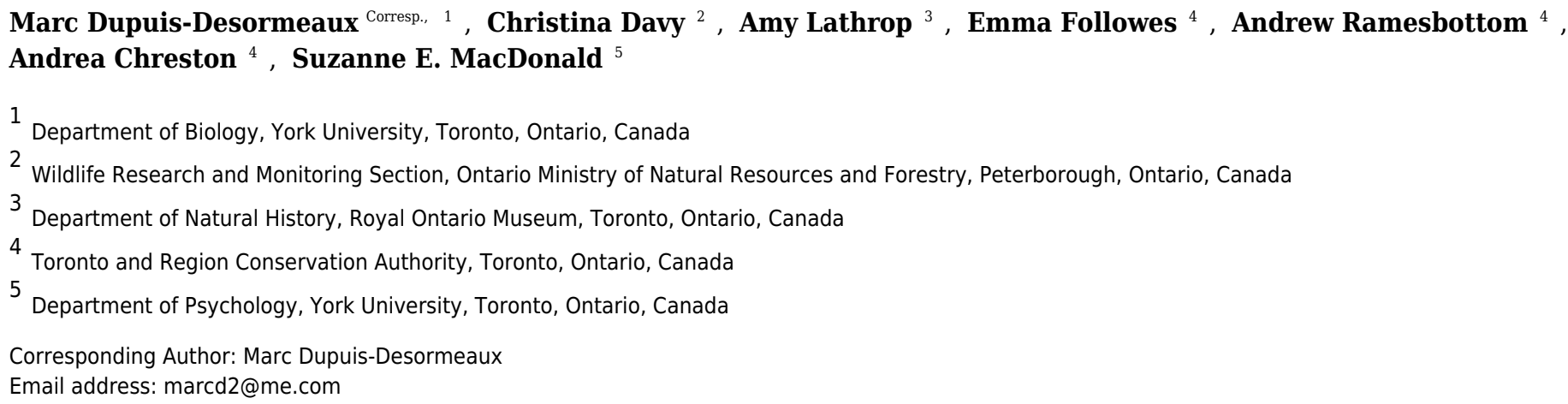

Conservation authorities invest heavily in the restoration and/or creation of wetlands to counteract the destruction of habitat caused by urbanization. Monitoring the colonization of these new wetlands is critical to an adaptive management process. We conducted a turtle mark-recapture survey in a 250 ha artificially created wetland complex in a large North American city (Toronto, Ontario). We found that two of Ontario's eight native turtle species (Snapping turtle, Chelydra serpentina, and Midland Painted turtle, Chrysemys picta marginata) were abundant and both were confirmed nesting. The Blanding's turtle (Emydoidea blandingii) was present but not well established. Species richness and turtle density were not equally distributed throughout the wetland complex. We noted Snapping turtles almost exclusively populated one water body, while other areas of the wetland had a varying representation of both species. The sex ratios of both Snapping and Midland Painted turtles were 1:1. We tracked the movement of Snapping and Blanding's turtles and found that most turtles explored at least two water bodies in the park, that females explored more water bodies than males, and that $95 \%$ of turtles showed fidelity to individual overwintering wetlands. We performed DNA analysis of two Blanding's turtles found in the created wetlands and could not assign these turtles to any known profiled populations. The genetic data suggest that the turtles probably belong to a remnant local population. We discuss the implications of our results for connectivity of artificial wetlands and the importance of the whole wetland complex to this turtle assemblage. 
Colonization and usage of an artificial urban wetland complex by freshwater turtles

Marc Dupuis-Désormeaux ${ }^{1}$, Christina Davy² ${ }^{2}$ Amy Lathrop ${ }^{3}$, Emma Followes ${ }^{4}$, Andrew

Ramesbottom $^{4}$, Andrea Chreston ${ }^{4}$, Suzanne E. MacDonald ${ }^{5}$

${ }^{1}$ Department of Biology, York University, Toronto, ON, M3J 1P3, Canada;

${ }^{2}$ Wildlife Research and Monitoring Section, Ontario Ministry of Natural Resources and Forestry, Trent University, 2140 East Bank Drive, Peterborough, Ontario K9J 7B8 Canada

${ }^{3}$ Royal Ontario Museum, Department of Natural History, 100 Queen's Park, Toronto, ON, M5S 2C6, Canada

${ }^{4}$ Toronto and Region Conservation Authority, Toronto, ON, L4K 5R6, Canada;

${ }^{5}$ Department of Psychology, York University, Toronto, ON, M3J 1P3, Canada.

Corresponding Author:

Marc Dupuis-Désormeaux

York University, 4700 Keele Street, Toronto, ON, M3J 1P3

Email address: marcd2@me.com 


\begin{abstract}
Conservation authorities invest heavily in the restoration and/or creation of wetlands to counteract the destruction of habitat caused by urbanization. Monitoring the colonization of these new wetlands is critical to an adaptive management process. We conducted a turtle mark-recapture survey in a 250 ha artificially created wetland complex in a large North American city (Toronto, Ontario). We found that two of Ontario's eight native turtle species (Snapping turtle, Chelydra serpentina, and Midland Painted turtle, Chrysemys picta marginata) were abundant and both were confirmed nesting. The Blanding's turtle (Emydoidea blandingii) was present but not well established. Species richness and turtle density were not equally distributed throughout the wetland complex. We noted Snapping turtles almost exclusively populated one water body, while other areas of the wetland had a varying representation of both species. The sex ratios of both Snapping and Midland Painted turtles were 1:1. We tracked the movement of Snapping and Blanding's turtles and found that most turtles explored at least two water bodies in the park, that females explored more water bodies than males, and that $95 \%$ of turtles showed fidelity to individual overwintering wetlands. We performed DNA analysis of two Blanding's turtles found in the created wetlands and could not assign these turtles to any known profiled populations. The genetic data suggest that the turtles probably belong to a remnant local population. We discuss the implications of our results for connectivity of artificial wetlands and the importance of the whole wetland complex to this turtle assemblage.
\end{abstract}




\section{Introduction}

2

3

4 5

Turtles play an important role in wetlands as omnivores, scavengers, predators, food sources, and nutrient recyclers, and some turtles are considered keystone species (Paine 1995). Turtle biomass can be very high in comparison to other vertebrates, measuring up to $877 \mathrm{~kg} / \mathrm{ha}$ in one temperate wetland (Congdon et al. 1986). Turtle populations are in decline in North America due to the loss and degradation of habitat, invasive species, pollution, disease, climate change and overexploitation (Ernst \& Lovich 2009). Road mortality is also a significant threat to several species (Beaudry et al. 2008) and is linked to reduced gene flow and male-skewed sex ratios (Gibbs \& Steen 2005).

Ontario has eight native species of turtles, and seven have been documented in Lake Ontario or its tributaries: Midland Painted (Chrysemys picta marginata), Common Snapping (Chelydra serpentina), Northern Map (Graptemys geographica), Spiny Softshell (Apalone spinifera spinifera), Eastern Musk (Sternotherus odoratus), Spotted (Clemmys guttata) and Blanding's (Emydoidea blandingii). A sevenyear synoptic trapping study concluded in 2010 at 16 sites along the Lake Ontario's shore found only four native turtle species present (Midland Painted, Snapping, Blanding's and Map). Low water quality and lack of submergent vegetation was likely to blame for the absence of Eastern Musk (DeCatanzaro \& Chow-Fraser 2010). The Spotted turtle is mostly found on the northern shore of Lake Erie, in the Georgian Bay and in a few scattered locations in southwest Ontario. Habitat loss restricts the Ontario distribution of the Spiny Softshell to a few disjunct populations located in south western Ontario.

Habitat loss due to urbanisation disproportionately affects wetland habitat, and is therefore critical to replace (Dudgeon et al. 2006; Mitsch \& Gosselink 2000). Wetlands provide important ecosystem services and are critical to preserve and restore (Bolund \& Hunhammar 1999; Woodward \& Wui 2001; Zedler \& Kercher 2005b). Wetlands represent approximately 14\% of Canada's land area, but development has reclaimed, contaminated or degraded their ecological functions in urban centres (Price \& Waddington 2000).

Wetlands provide valuable ecosystem services such as regulating water quantity, minimizing the impact of floods and storm water (Woodward \& Wui 2001; Zedler \& Kercher 2005a). Thus, the conservation, mitigation and/or restoration of wetlands is a major priority for the Government of Ontario and Ontario conservation authorities (Ontario Ministry of Natural Resources and Forestry 2017). Restoration ecology has focused a great deal on restoring and creating wetlands in urban areas to compensate for the rapid loss of wetland habitat due to urbanisation, yet restored wetlands consistently 
underperform reference wetlands on many ecological indicators (Maron et al. 2012; Suding 2011; Zedler $\&$ Callaway 1999). Restored wetlands can take $>100$ years to return to reference levels after restoration, or may become permanently altered by novel environmental conditions and never return to a reference state, especially in colder climates (Moreno-Mateos et al. 2012). Colonization of new wetlands by wildlife is dependent on the quality of the habitat, its age, size and its connectivity to source populations (Cosentino et al. 2010; Kadoya et al. 2004; Ruhi et al. 2009; Ruhi et al. 2012). As a major urban wetland conservation organization, Toronto and Region Conservation Authority (TRCA) has dedicated a large proportion of its annual $\mathrm{C} \$ 40$ million budget to monitoring, protecting and restoring wetlands in Canada's largest urban centre. The aim of this study was to investigate if turtles had colonized these artificial wetlands, to what extent, and for any Blanding's turtles, from what wild population are they most likely derived. Our secondary goal was to test if turtles that had recolonized restored wetlands were evenly distributed within the complex, and if species richness and distribution was similar to what could be expected in a natural Lake Ontario coastal wetland. We hope that monitoring and documenting the extent of any colonization will serve to gauge the success of these particular wetland creation efforts and inform other wetland creation or restoration projects.

\section{Methods}

\section{Study site:}

Tommy Thompson Park- Toronto, Ontario (4337’4’N 79²0’33”W)

The City of Toronto, Canada's largest metropolitan area, is built on a series of watersheds that cut along a north-south axis ending in Lake Ontario. Toronto is historically rich in wetland habitat that has been gradually lost due to urbanisation. In the 1960s, the Toronto Port Authority built a $5 \mathrm{~km}$ long breakwater (the Leslie Street Spit) into Lake Ontario to create additional lands for port infrastructure in conjunction with the opening of the St. Lawrence Seaway. As the Spit grew in size, native and non-native plants began to colonize the land, and it became an important stopover habitat for migrating birds. By 1991, large colonies of cormorants, gulls and herons nested at the Spit.

TRCA was tasked to develop and implement a master plan for a public park on the Spit, leading to the creation of Tommy Thompson Park (TTP). One component has been natural area enhancement, and TRCA has focused efforts on creating a varied wetland complex, to improve aquatic habitat including features such as aquatic vegetation and structural habitat (logs, root balls, stones, gravel beds, sandy 
62 beaches, etc.). TRCA continues to tweak wetland design at TTP using an iterative adaptive management

63 process that relies on active monitoring.

64 Description and History of the individual water bodies at TTP:

65

66

67

68

69

70

71

72

73

74

75

76

77

78

79

80

81

82

83

84

85

86

87

88

89

90

91

92

93
At TTP, there are three types of created water bodies forming the wetland complex: ponds, embayments and cells (Figure 1). Ponds are small and unconnected stand-alone bodies of water. There are two main ponds in the wetland complex, Triangle and Goldfish ponds. Goldfish Pond is the smallest pond and was accidentally created through asphalt disposal in the late 1970s. It measures approximately $500 \mathrm{~m}^{2}$ (0.05 ha). TRCA has not undertaken any restoration projects in Goldfish Pond and it has been allowed to naturalize without any intervention. Triangle Pond was constructed between 1975 and 1978 as a trial confined disposal facility and it covers 0.8 ha. TRCA capped the facility in 1997 and subsequently created a wetland by adding structural habitat (large stones, rocky shoals, woody materials), as well as aquatic and riparian vegetation in 1998.

The TTP embayments were created as coastal wetlands. Embayment A covers 6.25 ha and has benefited from two restoration projects; a) 2004-2005 to create spawning shoals on the east side of the embayment; b) 2009 to create backwater refuge and coastal wetland along the west and south shorelines. Embayment B covers 19 ha and has received two restoration projects; a) 1995-1997 to create Northern pike (Esox lucius) spawning channels in the sheltered backwater area to the east of the embayment, as well as structural habitat in the main embayment; b) 2011 to improve and enhance the coastal wetland conditions along the shoreline of the main embayment. Embayment $\mathrm{C}$ covers 24 ha and has seen three restoration projects; a) 1996-1998 to create structural, wetland and riparian habitat on the west portion of the embayment; b) 1998 to create pike spawning channels on the southeast shoreline; c) 2010 to improve coastal wetland habitat along the east shoreline along with additional structural habitat enhancements throughout the embayment. Embayment D covers 7 ha. In 2012-2014 a coastal wetland restoration project isolated the embayment from the lake through the construction of a berm and the installation of a fish and water level control structure. Embayments A, B and C are open to the lake, with backwaters and fish spawning channels, while Embayment D is connected to the lake via a fish gate with $7 \mathrm{~cm}$ vertical grates, impeding the travel of large invasive common carp (Cyprinus carpio) into the wetlands (French et al. 1999).

0 Cells were created as confined disposal facilities to store dredged material from the lower Don River and Keating Channel and eventually capped and transformed into wetlands. Cells are also connected to Lake Ontario via fish gates. Cell-1 was filled to capacity in 1985 and capped. TRCA created 11 ha of terrestrial and aquatic habitat in Cell-1, including a 7.7 ha coastal hemi-marsh between 2003- 
2006. A fish and water level control structure was installed in 2012. Cell-2 covers 10 ha and was filled to capacity in 1997. Cell 2 was capped and a coastal hemi-marsh wetland was created in 2015-2017 by adding structural habitat and vegetation. TRCA expected to install fish and water level control structures in late 2017-18 and to plant aquatic vegetation into 2018. Cell-3 measures 32 ha and is still accepting dredged material. TRCA does not expect to transform it into a wetland for some time, and hence this cell is currently devoid of emergent vegetation or structural habitat suitable for turtles.

\section{INSERT FIGURE 1 HERE}

\section{Survey methods:}

We studied the turtle population using three main methods: a capture-mark-recapture (CMR) methodology, very high frequency (VHF) tracking, and shore-based visual basking surveys.

\section{Capture-Mark-Recapture:}

We conducted a CMR study in 2016 and 2017, trapping turtles using hoop nets, basking traps or seine nets. CMR (Lecren 1965) is a robust method to determine population densities and trends (Pollock et al. 1990). We used one metre diameter- three-ring hoop nets (no.15 net with $6.25 \mathrm{~cm}$ mesh from Champlin Net Company, Jonesville, LA), basking traps (manufactured in-house, varying in size from 1 $\mathrm{m}^{2}$ to $2 \mathrm{~m}^{2}$, all with $6.25 \mathrm{~cm}$ mesh size) and a $30 \mathrm{~m}$ seine net (manufactured in-house, with $6.25 \mathrm{~cm}$ mesh). The size of the mesh precluded capturing very small turtles or juveniles, so our demographic information is skewed towards adults. Juveniles were captured opportunistically by hand. We baited the hoop traps with a variety of food, including frozen fish, canned cat food, canned sardines, and frozen chicken, depending on availability. Bait was placed in perforated bags, hung near the back of the traps at such a height that the bait was in the water. The trap was three-quarters submerged in water, in order to always have air available to trapped animals. Captured turtles were removed from the traps and processed on shore, where we recorded weight with a digital scale, body morphology with digital vernier calipers (plastron length, straight carapace length, carapace width, body depth, precloacal length, foreclaw length) and sex (if possible). For Midland Painted turtles, we identified males based on the elongated foreclaws and long tail, with the cloaca situated well beyond the limit of the carapace, compared to shorter foreclaws and tails in females. For Snapping turtles, we used the relative length of the posterior lobe vs. the base - cloaca tail measurement, and by gentle rocking to encourage penile eversion. For Blanding's turtles, males have a concave plastron and longer tail. We notched the marginal scutes of the shells to give each turtle a unique identifying number (Cagle, 1939). After processing, we returned turtles to the general area of the capture trap. We trapped for 25 days during the months of June and July 2016 and for 24 days in May and June 2017, using up to 20 hoop traps (13 traps in 2016 and 20 traps in 2017), 4 
126 basking traps and one seine net (2016 only). The seine net was only used one day in 2016 (one snapping

127 turtle captured) and was unavailable in 2017 and the basking traps had little success in 2016 and were not 128 used in 2017.

129 We trapped in each water body for a one to two-week period, depending on water body size and success 130 of trapping. Using a CMR protocol in successive years also allowed us to observe turtles moving from 131 one water body to another. As part of our invasive species protocol, we removed all captured Red-Eared 132 Sliders and transferred them to an adoption centre (Little RES Q, Pefferlaw, ON).

133 We used previously recorded locations of visually surveyed turtles to decide in which water body 134 we should trap. Staff and volunteers had reported many turtle sightings in both ponds, in all embayments 135 and in Cells 1 and 2. Although Cell-2 had previously recorded turtle activity, it was under further 136 restoration during the time of this study and was unsuitable for trapping. Consequently, we trapped in 137 seven distinct water bodies (see Table 1): Goldfish pond (2016/17), Triangle pond (2016/17), Cell-1 138 (2016/17), Embayments A (2016), B (2016), C (2017) and D (2016/17). Wetlands that produced very few 139 turtles in 2016 were not re-sampled in 2017.

\section{INSERT TABLE 1 HERE}

141 Statistics:

1. Population estimates: We applied the Chapman correction for small sample sizes to a simple twosample Lincoln-Petersen index to estimate population size (Chapman 1951). We estimated the population size for the two main turtle species at TTP where $N=[(\mathrm{K}+1)(\mathrm{n}+1)] /(\mathrm{k}+1) ; N$ is the estimated population, $\mathrm{n}$ is the individuals captured in $2016, \mathrm{~K}$ is the captured population in 2017 , and $\mathrm{k}$ is the population recaptured in 2017 that was marked from a previous capture.

2. Turtle sizes: Straight-line carapace length is reported using the mean \pm 1 standard deviation, with ranges reported as minimum-maximum.

3. Species representation: We tested for uniformity of individual species distribution through the various water bodies using a Chi-Square test.

4. Sex ratio: We performed a binomial test (nonparametric two-sided) to determine if the sex ratio of the two main turtle species was unbiased. The resulting probability, $p$, is two-tailed and is significant at $95 \%$ confidence level if the resulting $p$ is smaller than 0.025 or greater than 0.975 . 
157 Snapping turtles). Using a water epoxy, we glued the transmitters to the back of the carapace, generally

158 offset to one side, with the antenna trailing. We only attached transmitters to turtles $>300 \mathrm{~g}$ (transmitter

159 weight $<5 \%$ turtle body weight). ). In 2016, we aimed to get an even number of males and females and we

160 able to track eight male and eight female Snapping turtles and three female Blanding's turtles. After an

161 initial data investigation, we noticed that the female Snapping turtles were travelling greater distances

162 than the males. Therefore, in 2017 we became more interested in the movement of females, and

163 consequently added new transmitters only to new female Snapping turtles. We also removed the old VHF

164 transmitters (most of which had depleted their battery power) from any recaptured male Snapping turtles.

165 As a result, in 2017, we replaced the transmitters on all three female Blanding's turtles, on four recaptured

166 female Snapping turtles, added five new female Snapping turtles to the study, and removed old, non-

167 functional transmitters from three recaptured male Snapping turtles. We continued to track the remaining

168 five male Snapping turtles until we lost their VHF signals.

169 We tracked each individual turtle to a specific water body on a weekly basis during the active 170 period and once monthly over the winter. Hibernacula locations were determined in the fall by locating 171 turtles that had buried themselves under vegetation, logs, stumps or in the mud and reconfirming these

172 locations in the winter. The weekly time period will necessarily underestimate the movement of turtles

173 throughout the wetland complex but we used it as a baseline indication of the minimum habitat use and of 174 exploratory movement at the study site.

175 Visual surveys:

176 Staff and volunteers at the park also conducted regular visual surveys (using binoculars) of 177 basking turtles from shore and reported results back to the authors. Visual surveys offer a continuous data 178 set starting in 2004. Staff and volunteers also reported opportunistic observations of turtle nests 179 throughout the 2016 - 2017 study period.

\section{DNA Analysis:}

181 We collected blood samples from the Blanding's turtle by caudal venipuncture and stored these 182 samples on FTA cards (Whatman Inc., Little Chalfont, UK), for later DNA analysis to understand the 183 likely source of these individuals, which could have re-colonized TTP from a nearby population or 184 introduced to the site by humans after collection at a distant source site. DNA was extracted using 185 standard methods for nucleated blood (Smith and Burgoyne, 2004) and genotyped using 11 microsatellite 186 loci. These included loci GmuB08, GmuD16, GmuD21, GmuD28, GmuD55, GmuD87, GmuD88, 187 GmuD93, GmuD107, and GmuD121 (King \& Julian 2004), and loci Eb17 and Eb19 (Osentoski et al. 188 2002). Polymerase chain reaction (PCR) followed the recipe and thermocycling parameters detailed in 
189 Davy et al. (2014). We ran the TPP samples alongside a positive control DNA from a Blanding's turtle 190 genotyped previously in Davy et al. (2014) to ensure that the microsatellite genotypes obtained were 191 accurate and comparable to existing genotype data. The new genotypes were compared to an existing 192 database for Ontario Blanding's turtles (Davy et al. 2014) and used Geneclass2 (Piry et al. 2004) to assign 193 or exclude populations of origin for the new samples. We used Bayesian methods of assignment (Rannala

194 \& Mountain 1997), and Monte-Carlo resampling simulation algorithm (Paetkau et al. 2004), with 1,000

195 simulated individuals and $\alpha=0.05$, and then ran the analysis a second time using frequency-based 196 assignment (Paetkau et al. 2004).

197 Permits:

198 199

This study was conducted with the approval of York University's Animal Care Committee

200 (YUACC\#2016-16W- and \#2017-16W-R1) and under the Ontario Ministry of Natural Resources (Wildlife Scientific Collector's Authorization numbers \# 1083601 and 1085922) and Endangered Species 201 Act Permit for Species Protection or Recovery (AU-B-007-16 and AU-B-006-17).

202

203

204

205

206

207

208

209

210

211

212

213

214

215

216

217

\section{Results}

\section{Trapping surveys:}

We captured 126 turtles (97 new and 29 recaptured) over 496 trap-days (catch-per-unit-effort, CPUE, 25.4\%) in 2016 and 103 turtles (50 new and 53 recaptured) over 514 trap-days (CPUE 20.0\%) in 2017 (Table 2). Three of the four expected native turtle species were represented in our trapping: Midland Painted, Snapping, Blanding's and the introduced Red-Eared Slider (see Table 2). Based on the trapping results we estimated the number of individual Midland Painted turtles within TTP at 140 turtles $\pm 11(\mathrm{n}=$ $69, K=71, k=35)$ and the number of Snapping turtles at 35 turtles $\pm 3(n=20, K=24, k=14)$. Neither Midland Painted turtles $(\mathrm{df}=6, \mathrm{n}=105)=143.067, p<0.001)$ or Snapping turtles $(\mathrm{df}=7, \mathrm{n}=30)=23.867$, $p<0.001)$ were uniformly distributed across the individual capture locations. The proportion of Midland Painted to Snapping turtles in the whole wetland complex was 3.5:1 but varied by individual wetlands from 1:12 to 28:1. The male:female sex ratios of both Midland Painted (45:44, $p=0.584$ ) and Snapping turtles $(12: 15, p=0.351)$ did not statistically differ from the expected 1:1 ratio if the demographics of each species are taken as a whole over the entire TTP wetland complex. However, Midland Painted turtle sex ratios deviated from the expected 1:1 in two wetlands, where in Triangle Pond was male skewed, but 
218 just below significance $(1.7: 1, p=0.970)$ and Embayment $\mathrm{D}$ was significantly female skewed $(1: 3.5, \mathrm{p}=$ $2190.015)$.

INSERT TABLE 2 HERE

222

223 We report Midland Painted and Snapping turtle size and mass for the wetland complex and by

224 specific wetland in Table 3 below. We also captured three mature female Blanding's turtles (straight 225 carapace length $215 \mathrm{~mm}, 241 \mathrm{~mm}$ and $230 \mathrm{~mm}$, and mass of $1356 \mathrm{~g}, 2200 \mathrm{~g}, 1885 \mathrm{~g}$ respectively). Blood samples were successfully collected from two of these females.

227

INSERT TABLE 3 HERE

229

230

231 biomass for Midland Painted Turtle (MP) and Snapping Turtle (SN) for the most productive wetlands in Table 4. Note that because of the small size of Goldfish pond, density and biomass per hectare are artificially inflated.

INSERT TABLE 4 HERE

235

236

Our first method of quantifying movement through the site was based on the locations of recaptured turtles, and provided a minimum value of exploratory movement. Out of the 35 recaptured Midland Painted turtles, 7 (20\%) switched water bodies between captures, while only 1 (7\%) recaptured Snapping turtle was first captured in a different location.

241 (see Table 5). Of note, we had not captured common carp in 2016 in Embayment-D, but carp were able to 242 migrate into the embayment in 2017 as a consequence of record high lake levels in spring. In general, we 243 were able to release by-catch unharmed. However, there were a few occasions where fish caught in the 244 mesh of the hoop traps had drowned, or had been mortally injured and/or partially consumed by trapped 245 or nearby Snapping turtles. 
248 Habitat use by Snapping and Blanding's turtles (see Table 6 below)

249

250

251

252

253

254

255

256

257

258

259

260

261

262

263

264

265

266

267

268

269

270

271

272

273

274

Snapping turtles: We monitored a total of 21 Snapping turtles (8 males and 13 females), and 14 of these turtles ( 3 males and 11 females) were observed visiting more than one wetland. Of the 11 Snapping turtles that were initially captured in a wetland and then explored other water bodies ( 8 females and 3 males), 10 returned to their initial capture point for overwintering. The mean minimum distance travelled (straight line distance) was $0.5 \mathrm{~km}(0-2.5 \mathrm{~km})$ for males and $0.76 \mathrm{~km}(0-2.6 \mathrm{~km})$ for females. One female that was captured on land (in July 2017) left TTP to overwinter at an island, $1.6 \mathrm{~km}$ away. We tracked the turtles to hibernacula from mid-September to end of October (Figure 2). However, a few Snapping turtles in Embayment-D relocated in early November 2016, likely due to sudden drop in the water level caused by the demolition of a beaver dam located inside the fish gate. All of the Snapping turtles overwintered in shallow water (less than $1 \mathrm{~m}$ of water above the hibernaculum). Overwintering sites included: under vegetation mats (12), under logs, root balls and stumps (10), in mud flats with no vegetation above (4), at the edge or inside of beaver lodges (2), and under artificial structures (a wooden dock and a concrete slab).

Blanding's turtles: We tracked three female Blanding's turtles in 2016 and in 2017. All Blanding's turtles explored at least three wetlands and all three returned to overwinter in the same small pond. The most active Blanding's turtle traveled a minimum distance of $2.9 \mathrm{~km}$ over the summer of 2016 and $3.2 \mathrm{~km}$ in 2017 . These turtles overwintered together in both study years, in an area measuring approximately $10 \mathrm{~m}^{2}$ located in the deepest section of Goldfish pond ( $>1.5 \mathrm{~m}$ deep). The Blanding's turtles returned to their overwintering ponds by mid-September and remained active in that pond until mid-November of each year.

INSERT TABLE 6 HERE

INSERT FIGURE 2 HERE

$\underline{\text { Visual surveys }}$ 
275

276

277

278

279

280

281

282

283

284

285

286

287

288

289

290

291

292

293

294

295

296

297

298

299

300

301

302

303

304

Opportunistic basking surveys conducted by staff and citizen scientists (Table 7) identified the presence of two further species: a Northern Map turtle (Graptemys geographica) in Cell-2 and a suspected Spiny Softshell turtle (Apalone cf. spinifera) in Cell-1 and in Cell-2.

\section{INSERT TABLE 7 HERE}

Turtle nests were opportunistically discovered throughout the study period, either by observing a nesting turtle or by discovering a nest site that had been depredated. During our study period, we came across five Snapping turtles actively laying eggs along the gravel shoulder of the main spine road or in gravel side roads and trails. We did not observe any Midland Painted turtles actively laying eggs in a nest. Nesting activity was first observed in mid-June and as late as early August. We also discovered a number of other nest sites by finding dug out holes with scattered empty shells at the surface, presumably depredated. We did not identify any of the depredated nests to species.

\section{$\underline{\text { Results of the DNA analysis }}$}

Microsatellite locus Eb19 did not amplify, and loci GmuD55 and GmuD93 produced genotypes for the positive control that did not match those in the reference data from Davy et al. (2014). These three loci were excluded from further analyses. Neither turtle was strongly assigned to any previously profiled population: probability of assignment was $<0.65$ in all cases for the Bayesian analysis, and $<0.45$ in all cases for the frequency-based analysis. This result suggests that the two TTP Blanding's turtles originated from a population that was not represented in the reference data (including samples from the proximate Golden Horseshoe population), and that these assignment results should only be used to infer genetic similarity, but not genetic origin. The Bayesian analysis assigned the first individual most strongly to the Kawartha Highlands, and the second most strongly to Parry Sound District (the eastern shore of Georgian Bay).

\section{Discussion}

(1)

Two turtle species, the Midland Painted and the Snapping turtle, have successfully colonized our study site and established breeding populations. Both species are found in Lake Ontario at various sites within a few kilometres from TTP. Turtles were present in all surveyed areas of the TTP wetlands complex and were found in high densities in the two isolated ponds. Elsewhere, Painted turtle densities of greater than 100 individuals per hectare have been reported at a suburban site in North Carolina (Eskew et 
305 al. 2010), in New York (Zweifel 1989) and in Nebraska (Iverson et al. 2006). The juveniles of Midland

306 Painted and Snapping turtles were discovered opportunistically, as well many nests and nesting Snapping

307 turtles, which we interpreted as a sign of well-established populations. We attribute the lack of observed

308 nesting Midland Painted turtles to timing of oviposition in the late afternoons or early evenings (Rowe et

309 al. 2005), a time when researchers were not at TTP.

310 Blanding's turtles have started to re-colonize TTP, with sightings recorded since 2007, but remain

311 rare, and the lack of observed males suggests that this colonization remains precarious. The nearest

312 known occurrence of Blanding's turtles is approximately $15 \mathrm{~km}$ inland in the Rouge River. Blanding's

313 turtles can travel considerable distances. Females have been documented travelling distances of up to

$3143,479 \mathrm{~m}$ during nesting forays and nesting sites have been found as far as 1,850 $\mathrm{m}$ away from wetlands

315 (Millar \& Blouin-Demers 2011) however the genotype of the TTP samples could not be assigned to any

316 known population, and thus provides no evidence as to how this species arrived at TTP. The single

317 observation of Northern map turtle suggests that this species has only recently begun to colonize TTP.

318 Map turtles generally require high-quality water that supports mollusc prey and are found in clean lakes

319 and rivers. The TTP study site does support some crayfish species (both native and non-native) and snails,

320 so we would expect to eventually find Map turtles in greater numbers. In urban landscapes, introduced

321 exotic species common in the pet trade, such as the Red-Eared Slider turtle, are ubiquitous in easily

322 accessible wetlands and can have detrimental effects upon native turtles (Cadi \& Joly 2004). Although we

323 found some adult Red-Eared Slider turtles throughout the wetland complex, we did not find any evidence

324 of juveniles, suggesting that perhaps this exotic population was not successfully nesting. The presence of

325 the Spiny Softshell (Apalone cf. spinifera) at our site remains enigmatic. Although historically present but

326 rare in Lake Ontario, the native Eastern Spiny Softshell (Apalone spinifera spinifera) is now considered

327 locally extirpated in Lake Ontario (COSEWIC 2016). Recent sightings of Softshell turtles in the lake have

328 been attributed to non-native species, likely released.

329

Midland Painted and Snapping turtles are sympatric (Bodie et al. 2000), however, these species

330 have shown some different habitat preferences. At TTP, Midland Painted turtles preferred smaller ponds

331 with little or no fish and abundant shoreline vegetation consistent with past findings (Hughes et al. 2016;

332 Marchand \& Litvaitis 2004), whereas Snapping turtles were found in each wetland. Surprisingly,

333 Snapping turtles represented more than $20 \%$ of all individuals and $73 \%$ of the biomass of all turtles

334 captured at our site. The Midland Painted to Snapping turtle ratio of 3.5:1 was less skewed towards

335 Midland Painted turtles when compared to an 11:1 ratio found from a previous study of multiple sites in

336 Lake Ontario (DeCatanzaro \& Chow-Fraser 2010) and a ratio of 8.5:1 at the coastal Dunnville marshes

337 near Lake Erie (Brown 2016). Although the relative preponderance of Snapping turtles at TTP compared 
338 to natural sites stands out as unusual, it is not unique in artificial pond systems. A study of artificial ponds

339 in Pennsylvania found an overall 1.3:1 ratio between these species, with some ponds having a majority of

340 Snapping turtles (Hughes et al. 2016). A study of 88 wetlands, refuges and golf courses in upstate New

341 York found a ratio of 1:1.5, with Snapping turtles showing better body condition and more even sex ratios

342 in golf course wetlands than in protected areas (Winchell \& Gibbs 2016). The TTP Snapping turtle

343 density of 1.7 individuals per ha (biomass $10 \mathrm{~kg}$ per ha) approaches that of other sites in Ontario ranging

344 from 2 to 2.7 turtles per ha (biomass 13 to $18 \mathrm{~kg}$ per ha) at shallow artificial lakes, but nowhere near the

34558 turtles per ha (biomass $313 \mathrm{~kg}$ per ha) at a nutrient enriched pond (Galbraith et al. 1988). Cell-1 had

346 many Snapping turtles but was mostly devoid of Midland Painted turtles. TRCA had documented several

347 sightings of Midland Painted turtles in Cell-1 from 2004 to 2012, but none in 2013 and only one in 2014.

348 Common carp have destructive effects on shallow freshwater ecosystems including reducing

349 aquatic macrophyte cover (Lundholm \& Simser 1999) due to the carp's bottom-feeding behaviour

350 (Fletcher et al. 1985; Koehn 2004) and increasing water turbidity (Chow-Fraser 1999). We suspect that

351 the fish gate, equipped with $7 \mathrm{~cm}$ grate width, in Cell-1 has allowed smaller carp (total length $<50 \mathrm{~cm}$ ) to

352 access the cell in the spring (French et al. 1999). These carp may have grown over the summer to larger

353 than $50 \mathrm{~cm}$ total length thus becoming trapped by the fish gate inside the cell and unable to return to the

354 lake. The presence of carp on its own does not explain the lack of Midland Painted turtles in Cell-1 given

355 that Midland Painted turtles and carp coexist in Embayment D. However, the continuous presence of

356 large carp in combination with the clay substrate in Cell 1 that is easily disturbed and suspended

357 (Daviescolley et al. 1992; Harter \& Mitsch 2003) could have caused the degradation of the emergent

358 vegetation. Turbidity, per se, does not affect the ability of Painted turtles to locate prey species (Grosse et

359 al. 2010) but turbidity does negatively affect vegetation growth necessary for omnivorous species such as

360 the Midland Painted turtle (Parkos et al. 2003).

361 Although Snapping turtles are also omnivorous and prefer less turbid waters (Bodie et al. 2000),

362 adults may be better equipped to co-exist in carp-modified environments (Paterson et al. 2012). Snapping

363 turtles will readily feed on fish and evidence from our by-catch suggests that fish are abundant in Cell-1.

364 Safe and accessible terrestrial habitat between wetlands is an important characteristic of

365 successful wetland complexes (Burke \& Gibbons 1995; Gibbons 2003). At our site, turtles could move

366 freely through the park, as there was very little vehicular traffic, and they could also use the terrestrial

367 habitat to gain access to a variety of suitable nesting sites. The safety of the terrestrial habitat is a likely

368 contributor to the evenness of the sex ratios and the presence of turtles in all surveyed wetlands. Given the

369 amount of movement we documented between water bodies, we are inclined to consider the population

370 sex ratios at the wetland complex level. The sex ratios of both Midland Painted and Snapping turtles 
371 across the whole wetland complex were remarkably even. The evenness of the sex ratio at our site is

372 notable given that turtle sex ratios have been showing a male bias in North America (Gibbs \& Steen

373 2005) as well as in Ontario (DeCatanzaro \& Chow-Fraser 2010) attributed to the higher risks of vehicle

374 collisions to females searching for nesting sites by the roadside (Aresco 2005; Steen et al. 2006). Possible

375 sources of observed sex-ratio bias could stem for local climatic conditions (both Midland Painted and

376 Snapping turtles exhibit temperature-dependent sex determination), differential exposure to predators

377 (Marchand \& Litvaitis 2004) and capture methods (Ream \& Ream 1966). Dupuis-Desormeaux et al.

378 (2017) found a heavily male-skewed sex ratio in Midland Painted turtles at a nearby urban wetland site

379 (Heart Lake Rd.) with a history of turtle road mortality. The TTP and Heart Lake Rd. study sites share

380 similar general climatic conditions (microhabitat differences aside), similar predator presence and used

381 the same capture methodology. Two key differences stand out between the TTP and Heart Lake Rd. study

382 sites: differences in traffic volume (fewer than 50 vehicles per day at TTP, mostly dump trucks, versus

383 5000-7500 vehicles per day at Heart Lake Rd.) and differences in the timing of that traffic (7:30 am to

384 4:15 pm, weekdays only at TTP, versus 24 hours per day, seven days per week at Heart Lake Rd.).

385 Therefore the times of highest traffic volume at the TTP site avoided the peak nesting times (early

386 morning or late afternoon) for these two turtles species (Obbard \& Brooks 1981; Rowe et al. 2005). We

387 did not set out to study road mortality versus sex-ratios at TTP, and consequently have no data on TTP

388 road mortality; however given the above described similarities and differences between sites, we are

389 inclined to speculate that the lack of vehicular traffic at TTP contributes to the evenness of the observed 390 sex-ratio.

391 The results of our recapture and our tracking study revealed that Midland Painted, Snapping and

392 Blanding's turtle species visited all of the surveyed water bodies inside the wetland complex.

393 Furthermore, some Snapping and Blanding's turtles explored large portions of the park during the

394 summer yet displayed site fidelity towards their ponds of capture for overwintering. Nesting site fidelity

395 has been documented in both Blanding's (Standing et al. 1999) and Snapping turtles (Loncke \& Obbarde

396 1977) as well as overwintering site fidelity (Brown \& Brooks 1994; Innes et al. 2008; Meeks \& Ultsch

397 1990). Snapping turtle hibernacula were distributed throughout the wetland complex and we noted three

398 pairs that overwintered in close proximity to each other (two male-female pairs and one female-female

399 pair). However, we did not find evidence of mass congregation at a communal site as has been reported

400 in some other populations (Meeks \& Ultsch 1990). The structure of the hibernacula was similar to what

401 has been reported in past studies at natural wetland sites (Brown \& Brooks 1994; Paisley et al. 2009) and

402 in that respect, the overwintering sites at the TTP artificial wetland site mimicked that found in natural

403 ponds. 
404

405

406

407

408

409

410

411

412

413

414

415

416

417

418

419

420

421

422

423

424

425

426

427

428

429

430

431

432

433

434

435

The overland movement of turtles will increase their exposure to predators. At TTP, we have documented many potential turtle predators, including Eastern coyote (Canis latrans), raccoon (Procyon lotor), otter (Lontra canadensis) and mink (Neovison vison). We noted several Midland Painted turtles with shell markings consistent with predator encounters, including bite marks, puncture wounds, missing carapace pieces, scratch marks and missing limbs. We also discovered many depredated turtle nests. Turtles seem to be colonizing the created wetlands despite the presence of predators, but we would have to monitor survivorship over time to understand exactly how predation impacts population growth at TTP.

\section{Conclusion}

The two Blanding's turtles were not strongly assigned to any previously genotyped populations (Davy et al., 2014) based on their microsatellite genotypes, indicating that they belonged either to a remnant population of turtles from the TTP area, or that they had been introduced to TTP from an entirely different area. Of the populations previously profiled by Davy et al. (2014), the genetic profiles of the TTP Blanding's turtles were most similar to the closest candidate populations, which were in the Kawartha Highlands and the east shore of Georgian Bay. Thus the genetic data suggest that the TTP Blanding's turtles probably belong to a remnant local population, although the possibility that they were introduced from elsewhere cannot be completely excluded. This result is most consistent with a colonization of TTP by Blanding's turtle from nearby areas (possibly the Rouge River), and a pattern of genetic isolation by distance between Blanding's turtle populations on the Canadian Shield, and remnant populations near Lake Ontario. Confirming this hypothesis would require genotyping a robust sample of turtles from the Rouge or elsewhere along the north-western shore of Lake Ontario, as this would allow frequency-based analyses of the similarity between the Rouge and TTP individuals. However, collecting sufficient samples from the Rouge would be challenging as the original population apparently declined rapidly following the urbanization of the Greater Toronto Area.

We conclude that the artificial wetland complex at TTP has provided adequate habitat to attract four native species and that two of these species are nesting and recruiting juveniles to the TTP populations. Many other factors can influence colonization success, including the connectivity of the surrounding landscape matrix, specific habitat suitability, predator density, and the particular dispersal ecology of neighbouring seed populations. We suggest regularly assessing the progress in the colonization of each individual water body of this artificial wetland complex and of extending the movement study to include specimens from the nearby reference wetlands to better assess colonization vectors. 
436

\section{Acknowledgments}

438 We would like to acknowledge the help of Peter Shuttleworth and Ben Shearer with trapping, processing 439 and fish identification. We also would like to thank the many volunteer naturalists who monitor the 440 wildlife at TTP on a daily basis, special thanks to Ian Sturdee, Don Johnston and Paul Xamin. Both the 441 Toronto Zoo Adopt-A-Pond Program and the Ontario Turtle Conservation Centre (Dr. Sue Carstairs) 442 provided advice and hands-on training.

443 
444

445

446

447

448

449

450

451

452

453

454

455

456

457

458

459

460

461

462

463

464

465

466

467

468

469

470

471

472

473

474

475

476

\section{REFERENCES}

Aresco MJ. 2005. The effect of sex-specific terrestrial movements and roads on the sex ratio of freshwater turtles. Biological Conservation 123:37-44. 10.1016/j.biocon.2004.10.006

Beaudry F, deMaynadier PG, and Hunter Jr ML. 2008. Identifying road mortality threat at multiple spatial scales for semi-aquatic turtles. Biological Conservation 141:2550-2563.

10.1016/j.biocon.2008.07.016

Bodie JR, Semlitsch RD, and Renken RB. 2000. Diversity and structure of turtle assemblages: associations with wetland characters across a floodplain landscape. Ecography 23:444-456. 10.1034/j.1600-0587.2000.230407.x

Bolund P, and Hunhammar S. 1999. Ecosystem services in urban areas. Ecological Economics 29:293301. 10.1016/s0921-8009(99)00013-0

Brown B. 2016. Freshwater Turtle Population Characteristics and Habitat Use within Ontario's Dunnville Marsh Area Master. University of Waterloo.

Brown GP, and Brooks RJ. 1994. Characteristics of and fidelity to hibernacula in a northern population of snapping turtles, chelydra-serpentina. Copeia:222-226. 10.2307/1446689

Burke VJ, and Gibbons JW. 1995. Terrestrial buffer zones and wetland conservation: A case study of freshwater turtles in a Carolina bay. Conservation Biology 9:1365-1369. 10.1046/j.15231739.1995.09061365.x

Cadi A, and Joly P. 2004. Impact of the introduction of the red-eared slider (Trachemys scripta elegans) on survival rates of the European pond turtle (Emys orbicularis). Biodiversity and Conservation 13:2511-2518. 10.1023/B:BIOC.0000048451.07820.9c

Chapman DG. 1951. Some Properties of the Hypergeometric Distribution with Applications to Zoological Sample Censuses. Berkeley and Los Angeles: University of California Press, 131-160.

Chow-Fraser P. 1999. Seasonal, interannual, and spatial variability in the concentrations of total suspended solids in a degraded coastal wetland of Lake Ontario. Journal of Great Lakes Research 25:799-813.

Congdon JD, Greene JL, and Gibbons JW. 1986. Biomass of fresh-water turtles - a geographic comparison. American Midland Naturalist 115:165-173. 10.2307/2425846

Cosentino BJ, Schooley RL, and Phillips CA. 2010. Wetland hydrology, area, and isolation influence occupancy and spatial turnover of the painted turtle, Chrysemys picta. Landscape Ecology 25:1589-1600. 10.1007/s10980-010-9529-3

COSEWIC. 2016. Assessment and Status Report on the Spiny Softshell Apalone spinifera in Canada. In: Canada CotSoEWi, editor. Ottawa. p xiii +38 . 
477

478

479

480

481

482

483

484

485

486

487

488

489

490

491

492

493

494

495

496

497

498

499

500

501

502

503

504

505

506

507

508

509

510

Daviescolley RJ, Hickey CW, Quinn JM, and Ryan PA. 1992. Effects of clay discharges on streams .1. Optical-properties and epilithon. Hydrobiologia 248:215-234. 10.1007/bf00006149

Davy CM, Bernardo PH, and Murphy RW. 2014. A Bayesian approach to conservation genetics of Blanding's turtle (Emys blandingii) in Ontario, Canada. Conservation Genetics 15:319-330. 10.1007/s10592-013-0540-5

DeCatanzaro R, and Chow-Fraser P. 2010. Relationship of road density and marsh condition to turtle assemblage characteristics in the Laurentian Great Lakes. Journal of Great Lakes Research 36:357-365. 10.1016/j.jglr.2010.02.003

Dudgeon D, Arthington AH, Gessner MO, Kawabata ZI, Knowler DJ, Leveque C, Naiman RJ, PrieurRichard AH, Soto D, Stiassny MLJ, and Sullivan CA. 2006. Freshwater biodiversity: importance, threats, status and conservation challenges. Biological Reviews 81:163-182. $10.1017 / \mathrm{s} 1464793105006950$

Dupuis-Desormeaux M, D'Elia V, Cook C, Pearson J, Adhikari V, and MacDonald SE. 2017. Remarkable Male Bias In A Population Of Midland Painted Turtles (Chrysemys Picta Marginata) In Ontario, Canada. Herpetological Conservation and Biology 12:225-232.

Ernst CH, and Lovich JE. 2009. Turtles of the United States and Canada. Baltimore: John Hopkins University Press.

Eskew EA, Price SJ, and Dorcas ME. 2010. Survivorship and Population Densities of Painted Turtles (Chrysemys picta) in Recently Modified Suburban Landscapes. Chelonian Conservation and Biology 9:244-249. 10.2744/ccb-0823.1

Fletcher AR, Morison AK, and Hume DJ. 1985. Effects of carp, cyprinus-carpio 1, on communities of aquatic vegetation and turbidity of waterbodies in the lower goulburn river basin. Australian Journal of Marine and Freshwater Research 36:311-327.

French JRP, Wilcox DA, and Nichols SJ. 1999. Passing of northern pike and common carp through experimental barriers designed for use in wetland restoration. Wetlands 19:883-888.

Galbraith DA, Bishop CA, Brooks RJ, Simser WL, and Lampman KP. 1988. Factors affecting the density of populations of common snapping turtles chelydra-serpentina-serpentina. Canadian Journal of Zoology 66:1233-1240.

Gibbons JW. 2003. Terrestrial habitat: A vital component for herpetofauna of isolated wetlands. Wetlands 23:630-635. 10.1672/0277-5212(2003)023[0630:thavcf]2.0.co;2

Gibbs JP, and Steen DA. 2005. Trends in sex ratios of turtles in the United States: Implications of road mortality. Conservation Biology 19:552-556. 10.1111/j.1523-1739.2005.000155.x

Grosse AM, Sterrett SC, and Maerz JC. 2010. Effects of Turbidity on the Foraging Success of the Eastern Painted Turtle. Copeia:463-467. 10.1643/ce-09-162 
511 Harter SK, and Mitsch WJ. 2003. Patterns of short-term sedimentation in a freshwater created marsh.

512

513

514

515

516

517

518

519

520

521

522

523

524

525

526

527

528

529

530

531

532

533

534

535

536

537

538

539

540

541

542

543

Journal of Environmental Quality 32:325-334.

Hughes DF, Tegeler AK, and Meshaka WE. 2016. Differential use of ponds and movements by two species of aquatic turtles (chrysemys picta marginata and chelydra serpentina serpentina) and their role in colonization. Herpetological Conservation and Biology 11:214-231.

Innes RJ, Babbitt KJ, and Kanter JJ. 2008. Home range and movement of Blanding's Turtles (Emydoidea blandingii) in New Hampshire. Northeastern Naturalist 15:431-444. 10.1656/1092-619415.3.431

Iverson JB, Baker TJ, and Dishong BD. 2006. Natural history notes: Chrysemys picta bellii (Western Painted Turtle): Density and biomass. Herpetological Review 37:341.

Kadoya T, Suda S, and Washitani I. 2004. Dragonfly species richness on man-made ponds: effects of pond size and pond age on newly established assemblages. Ecological Research 19:461-467. 10.1111/j.1440-1703.2004.00659.x

King TL, and Julian SE. 2004. Conservation of microsatellite DNA flanking sequence across 13 Emydid genera assayed with novel bog turtle (Glyptemys muhlenbergii) loci. Conservation Genetics 5:719-725. 10.1007/s10592-004-1854-0

Koehn JD. 2004. Carp (Cyprinus carpio) as a powerful invader in Australian waterways. Freshwater Biology 49:882-894. 10.1111/j.1365-2427.2004.01232.x

Lecren ED. 1965. A note on the history of mark-recapture population estimates. Journal of Animal Ecology 34:453-454.

Loncke DJ, and Obbarde ME. 1977. Tag success, dimensions, clutch size and nesting-site fidelity for snapping turtle, chelydra-serpentina, (reptilia, testudines, chelydridae) in algonquin-park, ontario, canada. Journal of Herpetology 11:243-244. 10.2307/1563158

Lundholm JT, and Simser WL. 1999. Regeneration of submerged macrophyte populations in a disturbed Lake Ontario coastal marsh. Journal of Great Lakes Research 25:395-400.

Marchand MN, and Litvaitis JA. 2004. Effects of habitat features and landscape composition on the population structure of a common aquatic turtle in a region undergoing rapid development. Conservation Biology 18:758-767. 10.1111/j.1523-1739.2004.00019.x

Maron M, Hobbs RJ, Moilanen A, Matthews JW, Christie K, Gardner TA, Keith DA, Lindenmayer DB, and McAlpine CA. 2012. Faustian bargains? Restoration realities in the context of biodiversity offset policies. Biological Conservation 155:141-148. 10.1016/j.biocon.2012.06.003

Mathew CGP. 1984. The Isolation of High Molecular Weight Eukaryotic DNA. In: Walker JM, ed. Nucleic Acids Methods in Molecular Biology: Humana Press, 31-34. 
544 Meeks RL, and Ultsch GR. 1990. Overwintering behavior of snapping turtles. Copeia:880-884.

545

546

547

548

549

550

551

552

553

554

555

556

557

558

559

560

561

562

563

564

565

566

567

568

569

570

571

572

573

574

575

576

577

$10.2307 / 1446460$

Millar CS, and Blouin-Demers G. 2011. Spatial Ecology and Seasonal Activity of Blanding's Turtles (Emydoidea blandingii) in Ontario, Canada. Journal of Herpetology 45:370-378.

Mitsch WJ, and Gosselink JG. 2000. The value of wetlands: importance of scale and landscape setting. Ecological Economics 35:25-33. 10.1016/s0921-8009(00)00165-8

Moreno-Mateos D, Power ME, Comin FA, and Yockteng R. 2012. Structural and Functional Loss in Restored Wetland Ecosystems. PLoS Biology 10. 10.1371/journal.pbio.1001247

Obbard ME, and Brooks RJ. 1981. A radio-telemetry and mark-recapture study of activity in the common snapping turtle, chelydra-serpentina. Copeia:630-637.

Ontario Ministry of Natural Resources and Forestry. 2017. A Wetland Conservation Strategy for Ontario 2017-2030. Toronto, Ontario: Queen's Printer for Ontario. p 52.

Osentoski MF, Mockford S, Wright JM, Snyder M, Herman B, and Hughes CR. 2002. Isolation and characterization of microsatellite loci from the Blanding's turtle, Emydoidea blandingii. Molecular Ecology Notes 2:147-149. 10.1046/j.1471-8286.2002.00176.x

Paetkau D, Slade R, Burden M, and Estoup A. 2004. Genetic assignment methods for the direct, real-time estimation of migration rate: a simulation-based exploration of accuracy and power. Molecular Ecology 13:55-65. 10.1046/j.1365-294X.2004.02008.x

Paine RT. 1995. A conversation on refining the concept of keystone species. Conservation Biology 9:962964. 10.1046/j.1523-1739.1995.09040962.x

Paisley RN, Wetzel JF, Nelson JS, Stetzer C, Hamernick MG, and Anderson BP. 2009. Survival and Spatial Ecology of the Snapping Turtle, Chelydra serpentina, on the Upper Mississippi River. Canadian Field-Naturalist 123:329-337.

Parkos JJ, Santucci VJ, and Wahl DH. 2003. Effects of adult common carp (Cyprinus carpio)on multiple trophic levels in shallow mesocosms. Canadian Journal of Fisheries and Aquatic Sciences 60:182-192. 10.1139/f03-011

Paterson JE, Steinberg BD, and Litzgus JD. 2012. Generally specialized or especially general? Habitat selection by Snapping Turtles (Chelydra serpentina) in central Ontario. Canadian Journal of Zoology-Revue Canadienne De Zoologie 90:139-149. 10.1139/z11-118

Piry S, Alapetite A, Cornuet JM, Paetkau D, Baudouin L, and Estoup A. 2004. GENECLASS2: A software for genetic assignment and first-generation migrant detection. Journal of Heredity 95:536-539. 10.1093/jhered/esh074

Pollock KH, Nichols JD, Brownie C, and Hines JE. 1990. Statistical-inference for capture-recapture experiments. Wildlife Monographs:1-97.

PeerJ reviewing PDF | (2018:01:23034:2:1:NEW 16 Jul 2018) 
578 Price JS, and Waddington JM. 2000. Advances in Canadian wetland hydrology and biogeochemistry.

579

580

581

582

583

584

585

586

587

588

589

590

591

592

593

594

595

596

597

598

599

600

601

602

603

604

605

606

607

608

609

610

Hydrological Processes 14:1579-1589. 10.1002/1099-1085(20000630)14:9<1579::aidhyp76>3.0.co;2-\#

Rannala B, and Mountain JL. 1997. Detecting immigration by using multilocus genotypes. Proceedings of the National Academy of Sciences of the United States of America 94:9197-9201. 10.1073/pnas.94.17.9197

Ream C, and Ream R. 1966. Influence of sampling methods on estimation of population structure in painted turtles. American Midland Naturalist 75:325-\&. 10.2307/2423395

Rowe JW, Coval KA, and Dugan MR. 2005. Nest placement, nest-site fidelity and nesting movements in midland painted turtles (Chrysemys picta marginata) on Beaver Island, Michigan. American Midland Naturalist 154:383-397. 10.1674/0003-0031(2005)154[0383:npnfan]2.0.co;2

Ruhi A, Boix D, Sala J, Gascon S, and Quintana XD. 2009. Spatial and temporal patterns of pioneer macrofauna in recently created ponds: taxonomic and functional approaches. Hydrobiologia 634:137-151. 10.1007/s10750-009-9896-4

Ruhi A, Sebastian OS, Feo C, Franch M, Gascon S, Richter-Boix A, Boix D, and Llorente G. 2012. Manmade Mediterranean temporary ponds as a tool for amphibian conservation. Annales De Limnologie-International Journal of Limnology 48:81-93. 10.1051/limn/2011059

Smith LM, Burgoyne LA 2004. Collecting, archiving and processing DNA from wildlife samples using FTA databasing paper. BMC Ecol 4:4.

Standing KL, Herman TB, and Morrison IP. 1999. Nesting ecology of Blanding's turtle (Emydoidea blandingii) in Nova Scotia, the northeastern limit of the species' range. Canadian Journal of Zoology-Revue Canadienne De Zoologie 77:1609-1614. 10.1139/cjz-77-10-1609

Steen DA, Aresco MJ, Beilke SG, Compton BW, Condon EP, Dodd CK, Forrester H, Gibbons JW, Greene JL, Johnson G, Langen TA, Oldham MJ, Oxier DN, Saumure RA, Schueler FW, Sleeman JM, Smith LL, Tucker JK, and Gibbs JP. 2006. Relative vulnerability of female turtles to road mortality. Animal Conservation 9:269-273. 10.1111/j.1469-1795.2006.00032.x

Suding KN. 2011. Toward an Era of Restoration in Ecology: Successes, Failures, and Opportunities Ahead. In: Futuyma DJ, Shaffer HB, and Simberloff D, eds. Annual Review of Ecology, Evolution, and Systematics, Vol 42, 465-487.

Winchell KM, and Gibbs JP. 2016. Golf courses as habitat for aquatic turtles in urbanized landscapes. Landscape and Urban Planning 147:59-70. 10.1016/j.landurbplan.2015.11.001

Woodward RT, and Wui YS. 2001. The economic value of wetland services: a meta-analysis. Ecological Economics 37:257-270. 10.1016/s0921-8009(00)00276-7 
611 Zedler JB, and Callaway JC. 1999. Tracking wetland restoration: Do mitigation sites follow desired

612 trajectories? Restoration Ecology 7:69-73. 10.1046/j.1526-100X.1999.07108.x

613 Zedler JB, and Kercher S. 2005a. Wetland resources: Status, trends, ecosystem services, and restorability.

$614 \quad$ Annual Review of Environment and Resources 30:39-74.

$615 \quad$ 10.1146/annurev.energy.30.050504.144248

616 Zedler JB, and Kercher S. 2005b. Wetland resources: Status, trends, ecosystem services, and restorability. 617 Annual Review of Environment and Resources, 39-74.

618 Zweifel RG. 1989. Long-term Ecological Studies on a Population of Painted Turtles, Chrysemys picta, on

619 Long Island, New York. American Museum Novitates 2952:1-55.

620

621

622 
Figure 1

Map of Tommy Thompson Park, Toronto, Ontario, Canada. TRCA image 2017. 


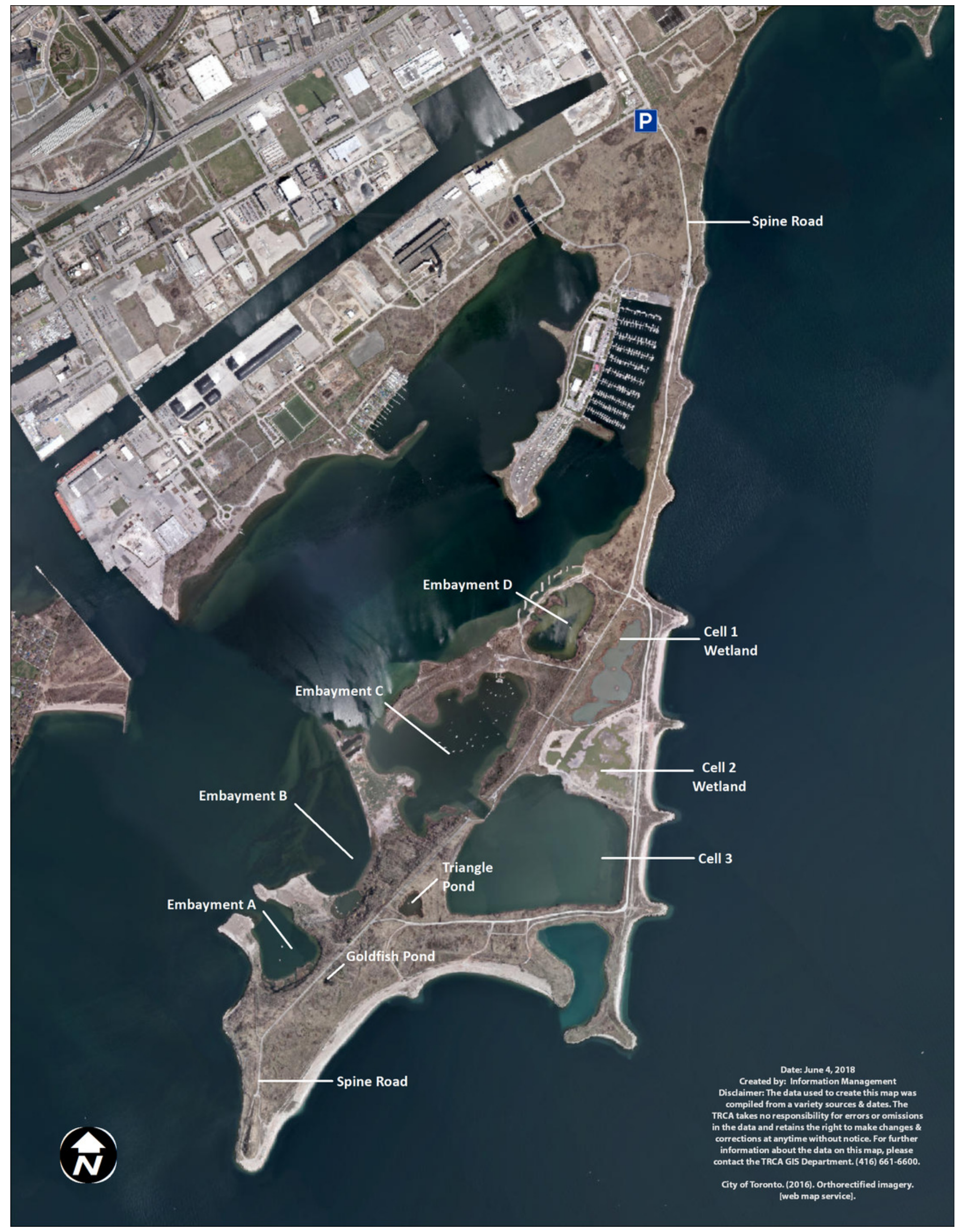


Figure 2

Map of overwintering locations of tracked Snapping and Blanding's turtles at TTP 201617.

Character codes: first letter represent species (B=Blanding's, S=Snapping) and following numeral indicates the specific individual turtle.

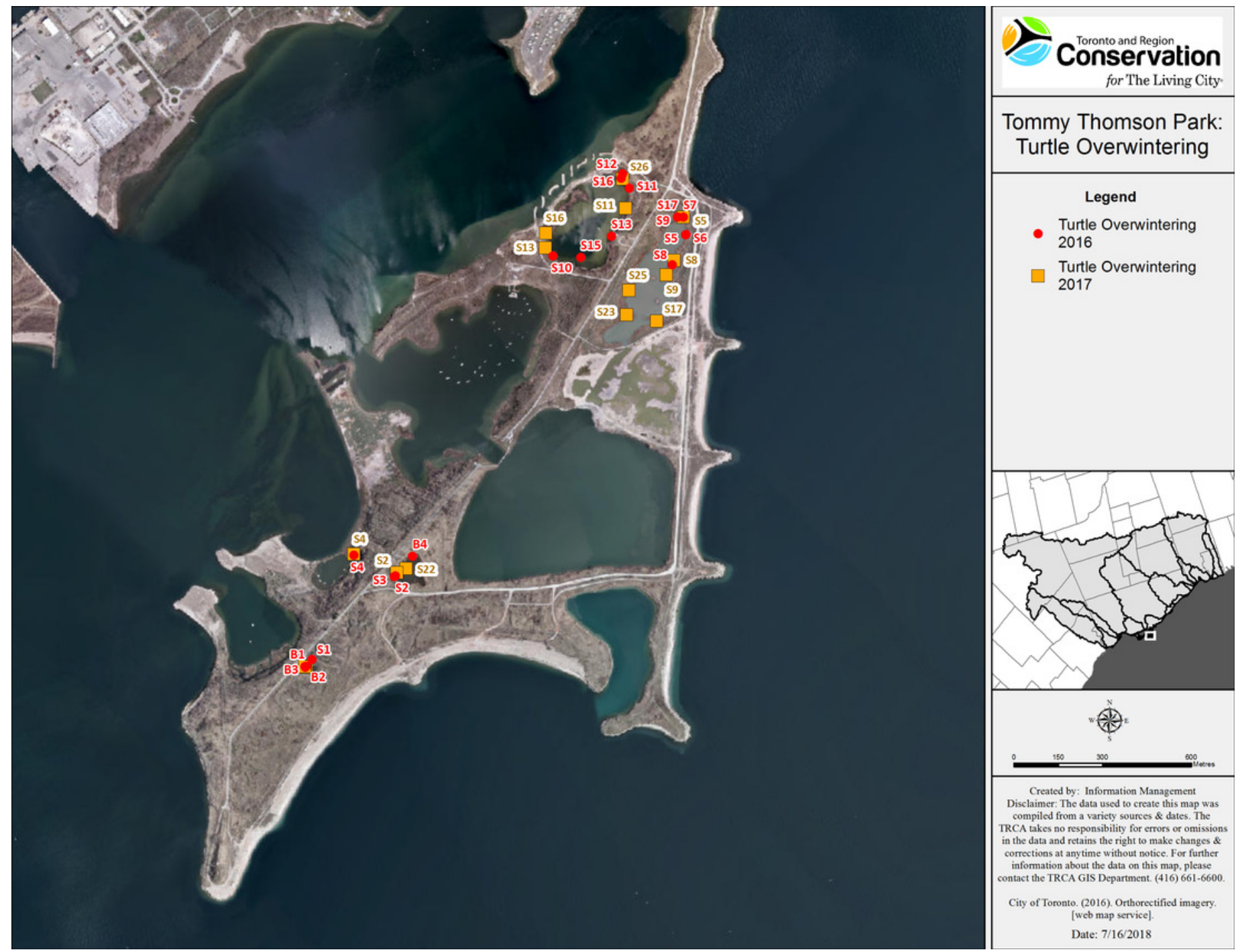




\section{Table $\mathbf{1}$ (on next page)}

Created water bodies at Tommy Thompson Park (TTP), describing type, size, and year of completion. 
1

\begin{tabular}{|l|l|l|l|}
\hline Name & Type & Size (ha) & $\begin{array}{l}\text { Year } \\
\text { completed }\end{array}$ \\
\hline Goldfish & Pond & 0.05 & $1970 \mathrm{~s}$ \\
\hline Triangle & Pond & 0.8 & 1998 \\
\hline Emb-A & Embayment & 6.25 & 2009 \\
\hline Emb-B & Embayment & 19 & 2011 \\
\hline Emb-C & Embayment & 24 & 2010 \\
\hline Emb-D & Embayment & 7 & 2014 \\
\hline Cell-1 & Cell & 6 & 2012 \\
\hline
\end{tabular}

2 


\section{Table 2 (on next page)}

Total number of new turtles captured in each water body surveyed at Tommy Thompson Park, 2016-17.

Each entry represents: total (male, female, unsexed juveniles) and ratio of Midland Painted turtle to Snapping Turtle (MP:SN). 
1

\begin{tabular}{|l|l|l|l|l|l|l|}
\hline $\begin{array}{l}\text { Species vs } \\
\text { Specific } \\
\text { Wetland }\end{array}$ & $\begin{array}{l}\text { Midland } \\
\text { Painted } \\
\text { (Chrysemys } \\
\text { picta } \\
\text { marginata })\end{array}$ & $\begin{array}{l}\text { Snapping } \\
\text { (Chelydra } \\
\text { serpentina })\end{array}$ & $\begin{array}{l}\text { Blanding's } \\
\text { (Emydoidea } \\
\text { blandingii) })\end{array}$ & $\begin{array}{l}\text { Red-Eared Slider } \\
\text { (Trachemys } \\
\text { scripta elegans) }\end{array}$ & $\begin{array}{l}\text { Total } \\
\text { number of } \\
\text { individual } \\
\text { turtles }\end{array}$ & $\begin{array}{l}\text { Ratio of } \\
\text { MP: SN }\end{array}$ \\
\hline Goldfish Pond & $28(14,13,1)$ & $1(1,0,0)$ & $3(0,3,0)$ & $1(1,0,0)$ & 33 & $28: 1$ \\
\hline Triangle Pond & $49(26,15,8)$ & $5(3,2,0)$ & 0 & $1(0,1,0)$ & 55 & $9.8: 1$ \\
\hline Cell-1 & $1(0,1,0)$ & $12(4,6,1)$ & 0 & $4(2,2,0)$ & 17 & $1: 12$ \\
\hline Emb-A & $1(1,0,0)$ & $1(0,0,1)$ & 0 & 0 & 2 & $1: 1$ \\
\hline Emb-B & $1(0,1,0)$ & $1(1,0,0)$ & 0 & 0 & 2 & $1: 1$ \\
\hline Emb-C & 0 & $1(0,1,0)$ & 0 & 0 & 1 & $0: 1$ \\
\hline Emb-D & $24(4,14,6)$ & $6(3,3,0)$ & 0 & $3(2,1,0)$ & 33 & $4: 1$ \\
\hline On land & $1(0,0,1)$ & $3(0,3,1)$ & 0 & 0 & 4 & $1: 3$ \\
\hline Total & $105(45,44,16)$ & $30(12,15,3)$ & $3(0,3,0)$ & $9(5,4,0)$ & 147 & $3.5: 1$ \\
\hline
\end{tabular}

2 


\section{Table 3(on next page)}

Sex, mean straight carapace length (SCL) and mass of adult Midland Painted Turtle, Chrysemys picta marginata, and Common Snapping Turtle, Chelydra serpentina, by wetland at the Tommy Thompson Park.

Sample sizes shown in parentheses, means are followed by \pm 1 standard deviation. 


\begin{tabular}{|l|l|l|l|l|}
\hline & \multicolumn{2}{|c|}{ Painted } & \multicolumn{2}{c|}{ Snapping } \\
\hline Wetland & Males & Females & Males & Females \\
\hline TTP - sample & $(45)$ & $(44)$ & $(12)$ & $(15)$ \\
SCL (mm) & $127 \pm 12$, & $146 \pm 19$ & $295 \pm 66$ & $245 \pm 53$ \\
Mass (g) & $263 \pm 63$ & $447 \pm 148$ & $7,265 \pm 4,252$ & $4,108 \pm 1,994$ \\
\hline Goldfish & $(14)$ & $(13)$ & $(1)$ & \\
SCL (mm) & $125 \pm 12$ & $149 \pm 9$ & 270 & \\
Mass (g) & $262 \pm 59$ & $482 \pm 80$ & 3,963 & \\
\hline Triangle & $(26)$ & $(15)$ & $(3)$ & $(2)$ \\
SCL (mm) & $125 \pm 11$ & $139 \pm 21$ & $368 \pm 33$ & $292 \pm 4$ \\
Mass (g) & $250 \pm 57$ & $401 \pm 162$ & $11,833 \pm 3,085$ & $5,025 \pm 671$ \\
\hline Cell-1 & & $(1)$ & $(4)$ & $(6)$ \\
SCL (mm) & & 161 & $319 \pm 31$ & $246 \pm 53$ \\
Mass (g) & & 532 & $9,035 \pm 2,269$ & $4,108 \pm 1,993$ \\
\hline Emb-D & $(4)$ & $(14)$ & $(3)$ & $(3)$ \\
SCL (mm) & $138 \pm 12$ & $148 \pm 23$ & $229 \pm 18$ & $202 \pm 11$ \\
Mass (g) & $327 \pm 79$ & $452 \pm 184$ & $3,200 \pm 625$ & $2,245 \pm 321$ \\
\hline Emb- C & & & & $(1)$ \\
SCL (mm) & & & & 171 \\
Mass (g) & & $(1)$ & & 1,200 \\
\hline Emb- B & & 153 & 195 & \\
SCL (mm) & 509 & 1,975 & \\
Mass (g) & & & & \\
\hline Emb- A & & & & \\
SCL (mm) & & & & \\
Mass (g) & & & & \\
\hline On Land & & & & \\
SCL (mm) & & & & \\
Mass (g) & & & & \\
\hline
\end{tabular}

1 


\section{Table 4 (on next page)}

Densities and biomass of captured turtles at selected productive wetlands in the Tommy Thompson Park, Toronto, ON. 2016-17 data.

Entries represent the total for all species including Red-eared sliders and Blanding's, with detail inside brackets for Painted (MPTU) and Snapping turtles (SNTU). 
1

\begin{tabular}{|l|l|l|l|l|l|}
\hline $\begin{array}{l}\text { Selected } \\
\text { wetland }\end{array}$ & $\begin{array}{l}\text { Area } \\
\text { (ha) }\end{array}$ & $\begin{array}{l}\text { Density- } \\
\text { Individual per ha: } \\
\text { All Species (MP, } \\
\text { SN) }\end{array}$ & $\begin{array}{l}\text { Mass } \\
\text { All Species } \\
(\mathrm{kg})\end{array}$ & $\begin{array}{l}\text { Mass: MP, SN } \\
(\mathrm{kg})\end{array}$ & $\begin{array}{l}\text { Biomass: Total } \\
(\mathrm{MP}, \mathrm{SN}) \\
\mathrm{kg} / \mathrm{ha})\end{array}$ \\
\hline Goldfish Pond & 0.05 & $660(560,20)$ & 22.939 & $9.988,3.963$ & $459(200,79)$ \\
\hline Triangle Pond & 0.8 & $69(61,6)$ & 60.470 & $13.204,45.505$ & $76(17,57)$ \\
\hline Cell-1 & 6.0 & $2.8(0.2,2)$ & 74.637 & $0.532,68.487$ & $12.4(0.1,11.4)$ \\
\hline Embayment D & 7.0 & $4.7(3.4,0.9)$ & 32.886 & $8.403,21.642$ & $4.7(1.2,3.1)$ \\
\hline Total & 13.85 & $10(7.4,1.7)$ & 190.932 & $32.127,139.597$ & $13.78(2.3,10)$ \\
\hline
\end{tabular}

2 


\section{Table 5 (on next page)}

Incidental fish capture (bycatch) by wetland area at the Tommy Thompson Park. Number of fish $(2016,2017)$. 
1

\begin{tabular}{|c|c|c|c|c|c|c|c|}
\hline Common name & Species & Goldfish & Triangle & Cell-1 & Emb-D & Emb-C & Total \\
\hline Common Carp & $\begin{array}{l}\text { Cyprinus } \\
\text { carpio }\end{array}$ & & & 8,13 & 0,14 & 1,1 & 9,28 \\
\hline Pumpkinseed & $\begin{array}{l}\text { Lepomis } \\
\text { gibbosus }\end{array}$ & & & 0,1 & & 0,2 & 0,3 \\
\hline Creek Chub & $\begin{array}{l}\text { Semotilus } \\
\text { atromaculatus }\end{array}$ & & 0,2 & & & & 0,2 \\
\hline Northern Pike & Esox lucius & & & 0,2 & & & 0,2 \\
\hline $\begin{array}{l}\text { Brown } \\
\text { Bullhead }\end{array}$ & $\begin{array}{l}\text { Ameiurus } \\
\text { nebulosus }\end{array}$ & & & 0,1 & & 0,1 & 0,2 \\
\hline Temperate bass & $\begin{array}{l}\text { Morone } \\
\text { chrysops }\end{array}$ & & & 0,2 & & & 0,2 \\
\hline $\begin{array}{l}\text { Largemouth } \\
\text { Bass }\end{array}$ & $\begin{array}{l}\text { Micropterus } \\
\text { salmonides }\end{array}$ & & & 0,1 & & & 0,1 \\
\hline Gizzard Shad & $\begin{array}{l}\text { Dorosoma } \\
\text { cepedianum }\end{array}$ & & & 0,1 & & & 0,1 \\
\hline Black Crappie & $\begin{array}{l}\text { Pomoxis } \\
\text { nigromaculatu } \\
S\end{array}$ & 0,1 & & & & & 0,1 \\
\hline Bluegill & $\begin{array}{l}\text { Lepomis } \\
\text { macrochirus }\end{array}$ & & 0,1 & & & & 0,1 \\
\hline Total & & 0,1 & 0,3 & 8,19 & 0,14 & 1,4 & 9,43 \\
\hline
\end{tabular}

2 


\section{Table 6(on next page)}

Movement of turtles equipped with a VHF transmitter during 2016/2017 at Tommy Thompson Park.

Individual water bodies inside the wetland complex are identified with a two-letter code as such: C1, C2, C3 (Cell\#), EA, EB, EC, ED (Embayment A, B, C, or D), G (Goldfish Pond), T (Triangle Pond). 


\begin{tabular}{|c|c|c|c|c|c|c|c|c|}
\hline Species & $\begin{array}{l}\text { Not } \\
\mathrm{ch} \\
\mathrm{Nu} \\
\mathrm{mb} \\
\mathrm{er}\end{array}$ & $\begin{array}{l}\mathrm{Se} \\
\mathrm{x}\end{array}$ & $\begin{array}{l}\text { Initial } \\
\text { capture } \\
\text { point }\end{array}$ & $\begin{array}{l}\text { Winter } \\
2016\end{array}$ & $\begin{array}{l}\text { Winter } \\
2017\end{array}$ & $\begin{array}{l}\text { Wetlands used } \\
\text { over study } \\
\text { period (some } \\
\text { are used } \\
\text { multiple times) }\end{array}$ & $\begin{array}{l}\text { Minimum } \\
\text { distance } \\
\text { covered 2016- } \\
2017\end{array}$ & $\begin{array}{l}\text { Size estimation } \\
\text { of habitat used } \\
\text { (ha) }\end{array}$ \\
\hline Blanding's & 1 & $\mathrm{~F}$ & $\mathrm{G}$ & $\mathrm{G}$ & $\mathrm{G}$ & $\begin{array}{l}\mathrm{C} 1, \mathrm{C} 2, \mathrm{C} 3, \\
\mathrm{EA}, \mathrm{EB}, \mathrm{EC}, \mathrm{G}, \\
\mathrm{T}\end{array}$ & $6.1 \mathrm{~km}$ & 112 \\
\hline Blanding's & 2 & $\mathrm{~F}$ & $\mathrm{G}$ & $\mathrm{G}$ & $\mathrm{G}$ & $\mathrm{EA}, \mathrm{EB}, \mathrm{G}$ & $0.8 \mathrm{~km}$ & 18 \\
\hline Blanding's & 3 & $\mathrm{~F}$ & $\mathrm{G}$ & $\mathrm{G}$ & $\mathrm{G}$ & $\mathrm{EA}, \mathrm{EB}, \mathrm{G}$ & $1.7 \mathrm{~km}$ & 18 \\
\hline Snapping & 2 & $\mathrm{~F}$ & $\mathrm{~T}$ & $\mathrm{~T}$ & $\mathrm{~T}$ & $\mathrm{~EB}, \mathrm{~T}$ & $0.4 \mathrm{~km}$ & 3 \\
\hline Snapping & 5 & $\mathrm{~F}$ & $\mathrm{C} 1$ & $\mathrm{C} 1$ & $\mathrm{C} 1$ & C1 & $0 \mathrm{~km}$ & 6 \\
\hline Snapping & 8 & $\mathrm{~F}$ & $\mathrm{C} 1$ & $\mathrm{C} 1$ & $\mathrm{C} 1$ & $\mathrm{C} 1, \mathrm{C} 2$ & $1.2 \mathrm{~km}$ & 17 \\
\hline Snapping & 9 & $\mathrm{~F}$ & $\mathrm{C} 1$ & $\mathrm{C} 1$ & $\mathrm{C} 1$ & $\mathrm{C} 1, \mathrm{ED}$ & $0.7 \mathrm{~km}$ & 30 \\
\hline Snapping & 11 & $\mathrm{~F}$ & ED & ED & ED & $\mathrm{C} 1, \mathrm{ED}$ & $0.7 \mathrm{~km}$ & 30 \\
\hline Snapping & 12 & $\mathrm{~F}$ & ED & ED & $\begin{array}{l}\text { No } \\
\text { signal }\end{array}$ & ED & $0 \mathrm{~km}$ & 8 \\
\hline Snapping & 13 & $\mathrm{~F}$ & ED & ED & ED & $\mathrm{C} 1, \mathrm{ED}$ & $0.7 \mathrm{~km}$ & 30 \\
\hline Snapping & 17 & $\mathrm{~F}$ & $\mathrm{C} 1$ & $\mathrm{C} 1$ & $\mathrm{C} 1$ & $\mathrm{C} 1, \mathrm{C} 2$ & $0.4 \mathrm{~km}$ & 17 \\
\hline Snapping & 22 & $\mathrm{~F}$ & $\mathrm{~T}$ & & $\mathrm{~T}$ & $\mathrm{~EB}, \mathrm{~T}$ & $0.6 \mathrm{~km}$ & 3 \\
\hline Snapping & 23 & $\mathrm{~F}$ & $\mathrm{C} 1$ & & $\mathrm{C} 1$ & $\mathrm{C} 1, \mathrm{ED}$ & $0.7 \mathrm{~km}$ & 30 \\
\hline Snapping & 25 & $\mathrm{~F}$ & $\begin{array}{l}\text { Road ED- } \\
\text { C1 }\end{array}$ & & $\mathrm{C} 1$ & $\mathrm{C} 1, \mathrm{EC}, \mathrm{ED}$ & $1.6 \mathrm{~km}$ & \\
\hline Snapping & 26 & $\mathrm{~F}$ & Road C1 & & ED & $\mathrm{C} 1, \mathrm{ED}$ & $0.3 \mathrm{~km}$ & 30 \\
\hline Snapping & 27 & $\mathrm{~F}$ & Road ED & & $\begin{array}{l}\text { Ward } \\
\text { Isl. }\end{array}$ & EA, ED, WI & $2.6 \mathrm{~km}$ & 168 \\
\hline Snapping & 1 & $\mathrm{M}$ & $\mathrm{G}$ & $\mathrm{G}$ & $\begin{array}{l}\text { Not } \\
\text { tracked }\end{array}$ & G & $0 \mathrm{~km}$ & 0.1 \\
\hline Snapping & 3 & $\mathrm{M}$ & $\mathrm{C} 1$ & $\mathrm{~T}$ & $\begin{array}{l}\text { Not } \\
\text { tracked }\end{array}$ & $\mathrm{C} 1, \mathrm{C} 2, \mathrm{C} 3, \mathrm{~T}$ & $2.5 \mathrm{~km}$ & 60 \\
\hline Snapping & 4 & $\mathrm{M}$ & EB & EB & EB & EB & $0 \mathrm{~km}$ & 2 \\
\hline Snapping & 6 & $\mathrm{M}$ & $\mathrm{C} 1$ & $\mathrm{C} 1$ & $\begin{array}{l}\text { No } \\
\text { signal }\end{array}$ & $\mathrm{C} 1$ & $0 \mathrm{~km}$ & 6 \\
\hline Snapping & 7 & $\mathrm{M}$ & $\mathrm{C} 1$ & $\mathrm{C} 1$ & $\begin{array}{l}\text { Not } \\
\text { tracked }\end{array}$ & $\mathrm{C} 1, \mathrm{ED}$ & $0.7 \mathrm{~km}$ & 30 \\
\hline Snapping & 10 & $\mathrm{M}$ & ED & ED & $\begin{array}{l}\text { No } \\
\text { signal }\end{array}$ & ED & $0 \mathrm{~km}$ & 8 \\
\hline Snapping & 15 & $\mathrm{M}$ & ED & ED & $\begin{array}{l}\text { No } \\
\text { signal }\end{array}$ & $\mathrm{EC}, \mathrm{ED}$ & $0.8 \mathrm{~km}$ & 31 \\
\hline Snapping & 16 & $\mathrm{M}$ & ED & ED & ED & ED & $0 \mathrm{~km}$ & 8 \\
\hline
\end{tabular}




\section{Table 7(on next page)}

Years of detected turtle species by visual surveys at TTP. 2004-2017 data. 
1

\begin{tabular}{|l|l|l|l|l|l|}
\hline Species/Wetland & Goldfish & Triangle & Cell-1 & Cell-2 & Emb-D \\
\hline Painted & $2004-2017$ & $2012-2017$ & $\begin{array}{l}2004-2012, \\
2014\end{array}$ & & $2004-17$ \\
\hline Snapping & & & 2012 & & \\
\hline Blanding's & $2007-2017$ & & & & \\
\hline Map & & & & 2015,2016 & \\
\hline Spiny Softshell & & & $\begin{array}{l}2006,2012, \\
2015,2016\end{array}$ & 2017 & \\
\hline
\end{tabular}

2 